\title{
Effect of Applying Various Time of Retinol Pretreatment on Improve Skin after Herbal Peeling
}

\author{
Seongeun Oh, Chang-Gok Chang ${ }^{*}$ \\ Department of Health and Cosmetics, Dongduk Women's University, Seoul, Korea
}

\author{
*Corresponding author: Chang-Gok Chang, \\ Department of Health and Cosmetics, \\ Dongduk Women's University, 60 Hwarang- \\ ro, 13-gil, Seongbuk-gu, Seoul 02748, \\ Korea \\ Tel.: +82 29404482 \\ Fax: +82 29404193 \\ Email: cgchang@dongduk.ac.kr
}

Received March 11, 2020

Revised November 01, 2020

Accepted November 24, 2020

Published December 30, 2020

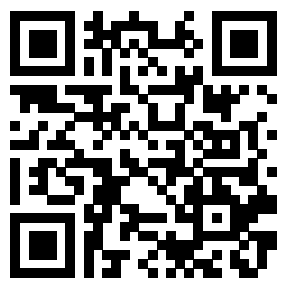

\begin{abstract}
Purpose: Retinol, a vitamin A derivative, is used as a pretreatment by applying it multiple times on the affected skin before herbal peeling to minimize side effects and to heal damaged skin. However, the effects of retinol as a pretreatment are unknown. Thus, this study evaluates the effects of retinol as a pretreatment for skin improvement. Methods: Middle-aged women were recruited as participants in this study and were divided into four groups, namely, without retinol pretreatment (G1), retinol pretreatment for 4 weeks (G2), 8 weeks (G3), and 12 weeks (G4). The test was conducted 15 times. Before peeling, participants in the G1, G3, and G4 groups were pretreated with retinol cream on their skin for the indicated time periods, whereas those in G1 did not receive the pretreatment. Skin erythema index, moisture content, transepidermal water loss (TEWL), and roughness were measured before the experiment, on the peeling day, and 1 and 2 weeks after peeling. Results: Significant differences in the skin erythema index, moisture content, TEWL, and roughness were found between the pretreated and non-pretreated groups. The pretreated groups experienced higher moisture content, lesser erythema, lower TEWL, and lesser roughness than the non-treated group. In addition, G4 had a larger improvement than G3, and G3 had a larger improvement than G2. Conclusion: The results showed that long-term use of retinol is effective in relieving erythema, dehydration, and skin irritation.
\end{abstract}

Keywords: Retinol, Pretreatment, Various time, Herbal peeling, Skin improvement

\section{Introduction}

신체의 모든 기관은 태어난 이후 노화 과정이 시작되며, 피부의 경우도 예외는 아니다. 신체의 기관 중 가장 큰 부분을 차지하는 피 부는 나이가 들어감에 따라 가장 분명하고 가시적인 노화의 정도 를 보여준다 (Kim et al., 2019; Kim et al., 2020). 특히 외부환경 에 노출되는 얼굴 피부의 노화를 지연 또는 개선하는 방법으로 필링 이 시행되고 있다(Kim et al., 2012; Kim \& Lee, 2010). 필링은 사 전적 의미로서는 '껍질 벗기기'라고 해석되며, 노화 각질제거로 인한 과색소 침착 완화, 여드름 완화 및 투명한 피부 유지, 표피 유극층의 keratinocyte 및 진피의 collagen과 그것들을 생산하는 fibroblast 또한 증식됨으로 간접 재생의 효과가 있는 것으로 알려져 있다(Kim et al., 2009).

그러나 필링은 피부 개선에 탁월한 효과를 보이지만 침범하는 피
부의 깊이가 깊을수록 피부 조직의 손상이 심해지고 재생이 잘 이뤄 지지 않아 흥터가 생기는 부작용이 존재한다(Kim et al., 2011).

화학적 필링에 이용되는 물질로는 alpha hydroxy acid (AHA), salicylic acid, trichloroacetic acid (TCA), beta hydroxy acid (BHA) 등이 있으며, 그 중 $\mathrm{AHA}$ 의 글리콜릭산(glycolic acid)을 가장 많 이 이용하고 있다. 글리콜릭산 필링의 깊이를 결정하는 것은 적용 방법, 적용성분, 적용시간에 따라 다르며, 진피에서 피부가 재생되 는 정도나 효과도 다르게 나타난다. 글리콜릭산의 농도와 $\mathrm{pH}$, 접 촉시간이 가장 중요하며, 중화시간이 초과되면 약물이 진피층 밑으 로 깊숙이 침투해 화상을 입는 경우가 있고 그로 인해 피부 문제점 이 악화될 수 있으므로 주의해야 한다. 전체적인 필링 시술 후 가 장 많이 발생하는 문제는 홍반이다. 홍반 증상의 경우 일시적으로 붉어졌다가 사라지는 정도의 가벼운 홍반부터, 갈색 색소가 침착된 듯 2-6개월 간 지속되는 증상도 존재한다(Kim \& Choi, 2018). 또 
한 기미로 인해 필링을 했던 시술 대상자에게 post inflammatory hyperpigmentation (PIH)의 문제가 나타나는 경우도 존재했다. 이 경우 $\mathrm{PIH}$ 증상은 시간이 지남에 따라 사라지기 때문에 자극요인을 피해 피부를 보호하며 사후 조치를 취해야 한다. 대부분은 필링 직 후 심한 피부 건조증을 느끼며 건조증상이 심해지면 홍반을 야기할 수 있고, 예민한 피부에서는 PIH 유발 가능성이 높게 나타난다. 또 한 필링 후 단순포진이 발생하는 경우도 있다. 단순포진의 증상은 일발적인 경우보다 증상이 심하고 오래가며 흥터를 남길 확률이 높 기 때문에 사전 예방이 중요하다.

약초필링은 물리적 자극을 통해 들어온 마이크로 미세침이 콜라 겐 재생을 자연스럽게 유도하고, 약초 성분의 미립자가 피부에 침 투해 세포를 활성화시킴으로써 각질과 노폐물을 제거하며 혈액순환 을 촉진해 새로운 세포가 빨리 형성되도록 하는 안전하면서도 효과 적인 필링법이다. 즉, 필링제를 피부에 바른 후 문지름의 물리적 자 극을 줌으로써 미체침이 피부에 박히게 되고 이것을 배출시키기 위 해 각질이 탈락과 재생을 반복하며 이 과정에서 죽은 각질을 탈락시 키고 새로운 피부를 재생시키는 원리의 시술법이다. 통증이 거의 없 고 $15 \mathrm{~min}$ 정도의 시술 시간이 현대인들의 욕구를 충족시키는 방법 이며 필링제에 함유된 여러 가지 유기산(organic acid)과 살리실산 (salicylic acid)등의 성분들에 의한 화학적 작용과 문지름의 물리적 작용을 겸한 필링 방법이다(Park \& Lee, 2018).).

그러나 약초필링도 다른 필링과 같이 필링 후 나타나는 피부 감 작성에서 완전히 배제될 수 없는데, 필링은 피부를 개선시키는 반면 홍반, 수분 부족, 피부 자극의 부작용을 동반한다(Deprez, 2007; Farber, 1998). 필링을 하게 되면 각질층의 장벽기능(barrier function)이 일시적으로 약해지고, 각질층이 얇고 예민하게 되므로 빛을 반사, 굴절시킬 수 있는 능력이 현저하게 줄어든다. 이에 따 라 피부에 침투되는 자외선의 양이 늘어나게 되므로 멜라노사이트 는 더 많이 자극을 받게 되고, 유전적 변형을 일으키게 되어 각종 부 작용을 일으킬 수 있다(Kim et al., 2009). 또한, 미세침 자극에 대 한 염증 반응으로서, 히스타민이 증가하여 모세혈관이 늘어나고 그 사이로 백혈구가 빠져나오면서 외피를 늘리게 되는데 이로 인해 각 질층의 불안정한 상태를 더 불안정하게 만들어 체내 수분의 증발이 가속화고 피부장벽 붕괴로 인해 유해 산소 증가 및 면역기능의 과 민성이 발생할 수 있고, 외부 유해인자가 쉽게 피부 속으로 침투해 들어올 수 있다(Kim et al., 2012; Lee et al., 2017; Park et al., 2003).

Kim et al. (1997)의 연구에서 화학적 박피술을 시행할 때 retinoic acid로 전 처치한 후 박피술을 시행하면 염증과 과색소 침 착(postinflammatory hyperpigmentation)을 줄일 수 있어 최근에 널리 쓰이고 있다. 비타민 A 유도체인 retinoic acid는 몇몇 피부질 환에 국소적 또는 전신적으로 사용되는 것으로 창상치유를 증진시 키고 유두진피(papillarydermis)내에서 콜라겐 합성을 촉진시키며 기미(melasma)나 염증후 과색소침착 등의 색소 병변을 호전시키는
작용이 있다고 하였다.

지금까지 연구에서 비타민 A는 mucopolysaccharides, collagen 과 fibronection 합성을 증가시키고 collagenase 합성을 억제하며, 섬유아세포를 자극하고 epidermal mitotic activity와 migration을 유도하는 것으로 알려져 있다(Duke \& Grevelink, 1998). 비타민 A 는 동물성 식품에서 얻어지는 레티놀이나 식물성 식품에서 얻어지 는 케로티노이드로 구분되고 비타민 $\mathrm{A}$ 라는 용어는 레티놀 변용체 의 생물활성을 나타내는 $\beta$-ionone 유도체를 총칭하며, 케로티노이 드와 레티놀은 우리 체내에서 비타민 $\mathrm{A}$ 로 전환될 수 있는 전구체이 다(Heinrich et al., 2003). 단위는 베타카로틴과 레티놀을 비타민 A 로 통일해서 표기하기 위해 IU란 단위를 사용하는데 비타민 $1 \mathrm{IU}$ 는 생물학적 활성으로 $0.3 \mu \mathrm{g}$ retinol 또는 $0.6 \mu \mathrm{g}$ beta-carotene, 1.2 $\mu \mathrm{g}$ other carotenoids와 동등하다(Olson, 1987).

레티노이드(retinoid)는 레티놀(retinol)과 자연적으로 발생하는 합 성유도체를 모두 포함하며, 레티놀(retinol), 레티날(retinal), 레티노 익산(retinoic acid)등의 3 가지 주요 화합물로 이루지지만 단 하나의 작용기만 다를 뿐 같은 화학구조를 가지고 있다. 주름을 개선하는 기 능성 화장품에 널리 사용되고 있는 레티놀(retinol)은 생체에서 레티 날(retinal) 및 레티노익산(retinoic acid)으로 변환되며, 생체 내에서 몇 개의 유도체가 발견되고 합성도 되기 때문에 이들을 통틀어 레티 노이드(retinoid)라고 부르고 있다(Underwood, 1984). 레티노이드 (retinoid)는 세포분화를 촉진하고 생체에 필요한 각종 단백질의 생 합성 등의 기능으로 주름 감소와 피부 노화 지연 기능을 가진다.

레티노익산(retinoic acid)은 피부 장벽을 얇게 해주어 필링이 고 르게 될 수 있도록 해주고, 필링 후 섬유아세포(fibroblast)나 상피 세포에서 fibronection합성을 증가시키고 collagenase나 일부 각질 (kerain)의 합성을 억제하는 작용하여 상처치유를 빠르게 하고 피부 의 색소침착을 줄여주기 때문에 임상가들이 화학적, 기계적, 레이 저 박피술 전의 전처치로 이용하고 있다(Popp et al., 1995; West \& Alster, 1999). Sohn et al. (2003)의 연구에서 레티노익산(retinoic acid)을 필링 전 전처치로 기간을 달리(1주, 4 주, 8 주, 12 주) 하였고, Ho et al. (2012)의 연구에서 피부장벽을 회복하는데 레티노익산 (retinoic acid)으로 3개월 치료할 때 가장 효과적이라고도 하였다.

그러나 레티노익산(retinoic acid)은 홍반, 인설, 건조, 작열감 등 의 자극 증상이 발생할 수 있어(Effendy et al., 1995) 농도에 차이 를 두어 피부과 의사의 처방 하에 제한적으로 사용되고 있다(Kim et al., 1997). 이에 비교적 피부 자극이 적고 레티노익산(retinoic acid) 과 화학구조가 같은 레티놀(retinol)를 약초필링 전에 적용하여 필링 후 동반되는 부작용을 최소화하고 필링 효과를 극대화하여 피부 개 선을 최대화하는데 연구의 목적이 있다.

이에 현재까지 임상연구는 레티노익산(retinoic acid)에만 머물러 에스테틱 영역에서의 레티놀 전 처치 연구는 아직 미흡한 실정에서, 필링 전 기간이 다른 레티놀 전처치군과 미 전처치군을 비교하여 필 링 후 발생하는 부작용을 최소화하고 피부 개선 효과를 검증 및 제 


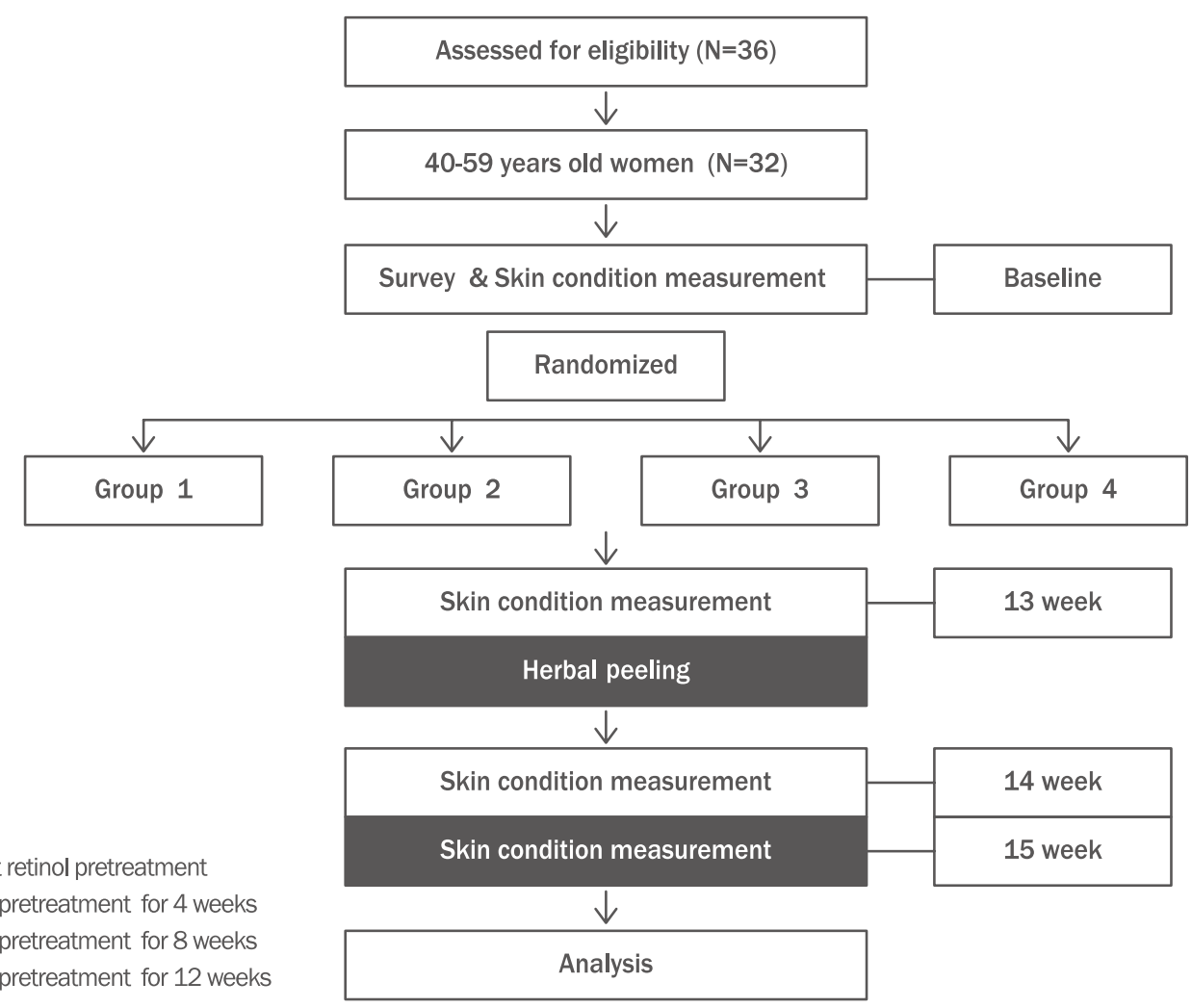

Figure 1. A flow diagram of sampling procedure.

시함으로써 레티놀 전처치 필링 프로그램의 지침서로 활용될 수 있 도록 이바지하고자 한다.

\section{Methods}

\section{1. 연구대상 및 연구방법}

1) 연구대상 및 연구설계

서울과 경기지역에 거주하는 35-49세 여성 32명을 대상으로 본 연구의 목적과 과정을 설명하고 이에 동의한 대상자들의 안면피부 상태를 측정하였다. 다른 피부 질환의 병력이 없고, 수유, 임신중 인 여성은 제외하였으며 최근 6 개월 이내 필링을 하지 않는 대상자 를 기준으로 랜덤으로 선발하였다. 본 연구는 동국대학교 생명윤리
위원회((Institution Review Board, IRB)의 승인을 받아 진행하였다 (승인번호: DDWU220-01). 본 연구의 임상결과를 알아보기 위하 여 약초필링 전 레티놀로 전처리 하지 않은 그룹을 Group 1 (대조 군), 약초필링 전 4주간(8-12주) 레티놀로 전처리한 그룹을 Group 2 (처치군1), 약초필링 전 8주간(4-12주) 레티놀로 전처리한 그룹을 Group 3 (처치군2), 약초필링 전 12주간(1-12주) 레티놀로 전처리 한 그룹을 Group 4 (처치군3)로 하였다(Table 1).

2) 연구설계

본 연구의 절차에 대해서 도식화하면 다음 Figure 1과 같다.

\section{2. 연구절차 및 방법}

1) 사전측정

Table 1. Experiment design of the subject

\begin{tabular}{|c|c|c|c|c|c|c|c|}
\hline Group & Baseline & 1-4 week & 5-8 week & 9-12 week & 13 week & 14 week & 15 week \\
\hline G1 & \multirow{4}{*}{ Skin measurement } & M & $M$ & $M$ & \multirow{4}{*}{$\begin{array}{c}\text { Skin } \\
\text { measurement } \\
\text { \& Peeling }\end{array}$} & \multirow{4}{*}{$\begin{array}{c}\text { Skin } \\
\text { measurement } \\
\text { (after } 1 \text { week } \\
\text { peeling) }\end{array}$} & \multirow{4}{*}{$\begin{array}{c}\text { Skin } \\
\text { measurement } \\
\text { (after } 2 \text { weeks } \\
\text { peeling) }\end{array}$} \\
\hline G2 & & M & M & $\mathrm{R}$ & & & \\
\hline G3 & & $M$ & $\mathrm{R}$ & $\mathrm{R}$ & & & \\
\hline G4 & & $\mathrm{R}$ & $\mathrm{R}$ & $\mathrm{R}$ & & & \\
\hline
\end{tabular}

$\mathrm{R}$, retinol cream; M, moisturizing cream; Skin measurement: erythema, moisture contents, TEWL, roughness. 
(1) 설문조사

연구대상자(처치군 1 , 처치군 2 , 처치군 3 , 대조군으로 구성된 총 36 명)에게 설문조사의 취지를 위하여 별도의 연구대상자 설명문 및 동의서를 설명한 후 프로그램 시작 전 인구통계학적 특성을 조사를 위한 설문조사를 한다.

\section{(2) 피부 상태 측정}

측정오차를 최소화하기 위하여 동일한 측정자가 동일한 실내환 경, 즉 실내온도는 $20-25^{\circ} \mathrm{C}$, 습도는 40-60\%로 유지된 관리실 내 에서 측정하며, 연구대상자는 실험 전(0주차), 필링 당일(13주차), 필링 1 주 후(14주차), 필링 2 주 후(15주차)로 총 4회에 걸쳐 동일한 측정부위와 동일한 압력을 위하여 본 연구자가 직접 피부 상태를 측 정한다.

\section{(1) 홍반 측정}

피부 표면의 홍반측정은 Mexameter MX 18 (Courage+Khazaka elctronic, Germany)을 이용하였다. 탐침을 사용하여 피부표면의 일정한 압력 $(91 \mathrm{~g} / \mathrm{cm} 2)$ 을 주어 측정하고 3 회 측정에 대한 평균값을 사용한다. 측정값은 대상자의 오른쪽 볼(눈꼬리에서 밑으로 $2 \mathrm{~cm}$ )의 동일부위를 3 번 반복 측정한 평균값을 임의 단위인 erythema index (EI)로 표시한다.

\section{(2) 수분 측정}

수분 측정기는 Moisture Checker (MY-707S; Scalar, Japan) 를 이용하였다. 왼쪽 볼의 광대빼 아랫부분에 대고 일정한 압력으로 $3-4 \mathrm{~s}$ 후에 가볍게 접촉시켜 수치를 3 번 측정하여 평균값을 산출하 였다. 최저 수치는 0 이고 최고 수치는 99 이다. 수치가 높을수록 수 분이 많음을 의미하며 수치가 낮을수록 수분이 적음을 의미한다.

(3) 경피 수분 손실(trans epidermal water loss, TEWL)측정 피부표면의 경피 수분손실의 측정은 Tewameter TM210 (Courage+Khazaka elctronic)을 이용한다. 기구를 측정 부위의 피 부에 수직으로 접촉하면 탐침 내에 있는 2 개의 습도 센서가 이를 인 지하여 자동으로 주부 위의 상대 습도 차이를 기초로 TEWL이 측정 되며 본 연구에서는 1 회 측정 시 $30 \mathrm{~s}$ 이상 수평을 유지한다. 대상자 들의 오른쪽 볼(눈꼬리에서 밑으로 $2 \mathrm{~cm}$ )을 $1 \mathrm{~s}$ 간격으로 측정하였
고 3 회 측정에 대한 평균값을 사용하며 단위는 $\mathrm{g} / \mathrm{h} / \mathrm{m}^{2}$ 로 표시한다.

\section{(4) 거칠기 측정}

SMS Premier 3.0 프로그램을 이용하여, KPLS Lens A041로 I Mode에서 60 배율로 사진을 찍으면 소릉과 소구의 높낮이에 따라 컬러화면으로 저장되어 수치로 나타내는 값을 3 회 반복 측정 후 평 균값을 기록한다. 최저 수치는 0 이고 최고 수치는 99 이며, 수치가 높을수록 거칠음을 의미한다. 피부 거칠기 측정은 세라마이드를 피 부에 적용한 후 $30 \mathrm{~min}$ 지나는 시점에서 측정하였고, 측정 부위는 왼쪽 볼(눈동자 중앙에서 수직 아래 코끝과 일직선이 되는 부분)을 측정한다. 단위는 pixel로 표시한다.

\section{2) 레티놀 적용 피부관리}

약초필링 전처리로써 군별로 레티놀의 적용 기간을 다르게 한다. 대조군 (G1)은 12 주간 토너 후 수분크림으로 셀프 피부관리를, 처치 군 1(G2)은 4주간, 처치군 2(G3)은 8주간, 처치군 3 (G4)은 12 주간 레티놀 적용 셀프 피부관리를 밤에 진행 한다.

\section{(1) 레티놀 제품}

본 실험에 사용한 레티놀은 식약처 허가받은 아모레퍼시픽 (Korea)에서 제조하는 $2500 \mathrm{IU}$ 레티놀을 임상 실험재료로 사용한 다.

(2) 홈케어로 사용되는 제품은 physiogel toner (Physiogel, Ireland), physiogel facial cream (Ireland)이다.

3) 레티놀 적용 약초필링 프로그램

약초필링 전처리로서의 레티놀 적용이 끝난 13 주 차에 약초필링 을 시행한다. 레티놀 미적용한 대조군(G1), 레티놀을 4주간 적용한 처치군 $1(\mathrm{G} 2), 8$ 주간 적용한 처치군 $2(\mathrm{G} 3)$ 와 12 주간 적용한 처치 군 $3(\mathrm{G} 4)$ 의 피부 개선 효과를 비교 분석하여 평가한다. 필링 이후 일주일간 메이크업하지 않는다.

\section{(1) 약초필링 제품}

본 실험에 사용된 약초필링 제품은 식약청 허가받은 한국 $\mathrm{M}$ 사의 B-Tox 제품을 사용하였다. B-Tox는 biosilica, calcium

\section{Table 2. Application of retinol}

\begin{tabular}{lccccc}
\hline Group & 1-4 week & 5-8 week & $9-12$ week & Toner & Moisturizing cream \\
G1 & T, M & T, M & T, M & $150 \mathrm{~mL}$ & $150 \mathrm{~mL}$ \\
G2 & T, M & T, M & T, R & $150 \mathrm{~mL}$ & $100 \mathrm{~mL}$ \\
G3 & T, M & T, R & T, R & $150 \mathrm{~mL}$ & $50 \mathrm{~mL}$ \\
G4 & T, R & T, R & T, R & $150 \mathrm{~mL}$ & $100 \mathrm{~mL}$ \\
\hline
\end{tabular}

$\mathrm{T}$, toner; $\mathrm{R}$, retinol cream; $\mathrm{M}$, moisturizing cream; G, group. 
phosphate, iodine 등 기존의 약초 필 성분과 미세침 다공구조로 미 네랄 공급과 필링을 동시에 진행한다는 장점이 있어 자극을 최소화 하기 위해 선택하였다.

\section{4) 사후 측정}

약초필링 프로그램은 13 주 차 연구대상자가 정해진 요일과 시간 에 1 회 $40 \mathrm{~min}$ 동안 약초필링 프로그램을 실시한 후 14 주 차와 15 주 차에 처치군과 대조군 32 명을 대상으로 관리 시작 전·후 같은 측 정 도구를 사용하여 홍반, 수분, TEWL, 거칠기를 측정한다.

\section{3. 시술 방법 및 절차}

1) 레티놀 적용 피부관리

레티놀 적용 피부관리는 Table 2 와 같다.

매일 저녁 클렌징과 토너 후 대조군(G1)은 12주간 토너 $150 \mathrm{~mL}$ 와 수분크림 $150 \mathrm{~mL}$ 를, 처치군 1 (G2)는 8주간 토너 $150 \mathrm{~mL}$ 와 수 분크림 $100 \mathrm{~mL}$ 와 레티놀 $50 \mathrm{~mL}$ 를, 처치군 2 (G3)은 4주간 토너 $150 \mathrm{~mL}$ 와 수분크림 $50 \mathrm{~mL}$ 와 레티놀 $100 \mathrm{~mL}$ 를 도포하였다. 처치 군3은 $\mathrm{G} 4$ 는 12 주간 토너 $150 \mathrm{~mL}$ 와 레티놀 $150 \mathrm{~mL}$ 를 도포하였다 (Table 2).

각각의 용량은 "레티놀이 모공각화증에 미치는 영향"의 Shin (2009) 연구에서 레티놀과 보습크림을 매일 오른쪽 어깨와 왼쪽 어 깨에 각각 매일 1 회 한달 간 총 $50 \mathrm{~mL}$ 씩 매일 1 달 사용한다는 것에 기초하고 있다. 크림의 하루 도포량은 약 1.6-1.7 mL로 강낭콩 정
도의 크기에 해당한다(화장품 샘플 용량은 $1 \mathrm{~mL}$ 이다).

2) 약초 필링 프로그램

클렌징, 필링, 마스크, 보호의 4단계로 시술하였으며 구체적 관리 방법은 다음과 같다.

(1) 클렌징 단계 $5 \mathrm{~min}$ 간 클렌징 로션(Aroma Milk Cleanser, Mesopharm $^{\circledR}$, Korea)을 이용하여 피부의 노폐물과 메이크업 잔 여물을 닦는다.

(2) 필링 단계 약초필링 (B-Tox, Mesopharm®)을 도포하고 15 $\min$ 간 부드럽게 마사지한 후 냉 습포와 토너를 이용하여 필링 제 품을 제거한다.

(3) 마스크 단계 마스크(Ultra Comfort Modelage Mask Mesopharm®)를 도포하고 $15 \mathrm{~min}$ 후 깨끗이 닦는다.

(4) 보호 단계 토너와 재생 크림(Aroma Milk Cleanser, Mesopharm®) 도포를 포함하여 $5 \mathrm{~min}$ 간 마무리한다.

\section{4. 자료분석과 통계적 방법}

본 연구의 실증분석은 모두 유의 수준 $5 \%$ 에서 검증하며, 통계처 리는 SPSSWIN 18.0 (IBM, USA) 프로그램을 사용하여 분석한다. 이에 본 연구를 수행하는 데 있어서 다음과 같은 통계처리 과정을 거친다.

첫째, 네 집단의 일반적 사항(인구통계학적 특성, 생활습관, 피부

Table 3. Test of homogeneity for general characteristics

\begin{tabular}{|c|c|c|c|c|c|c|c|}
\hline \multicolumn{2}{|c|}{ Variable } & G1 & G2 & G3 & G4 & $x^{2}$ & $p$ \\
\hline \multirow{2}{*}{ Age } & $30-39$ & $4(23.5)$ & $6(35.3)$ & $3(17.6)$ & $4(23.5)$ & \multirow{2}{*}{2.384} & \multirow{2}{*}{0.497} \\
\hline & $40-49$ & $4(26.7)$ & $2(13.3)$ & $5(33.3)$ & $4(26.7)$ & & \\
\hline \multirow{3}{*}{ Marital status } & Married & $5(27.8)$ & $3(16.7)$ & $5(27.8)$ & $5(27.8)$ & \multirow{3}{*}{6.061} & \multirow{3}{*}{0.416} \\
\hline & Single & $1(9.1)$ & $4(36.4)$ & $3(27.3)$ & $3(27.3)$ & & \\
\hline & Divorce & $2(66.7)$ & $1(33.3)$ & $0(0.0)$ & $0(0.0)$ & & \\
\hline \multirow{4}{*}{ Educational level } & High school & $0(0.0)$ & $1(20.0)$ & $2(40.0)$ & $2(40.0)$ & \multirow{4}{*}{9.000} & \multirow{4}{*}{0.437} \\
\hline & College & $4(50.0)$ & $1(12.5)$ & $1(12.5)$ & $2(25.0)$ & & \\
\hline & University & $3(20.0)$ & 5 (33.3) & $5(33.3)$ & $2(13.3)$ & & \\
\hline & Graduates school & $1(25.0)$ & $1(25.0)$ & $0(0.0)$ & $2(50.0)$ & & \\
\hline \multirow{4}{*}{ Working status } & Office work & $4(26.7)$ & $4(26.7)$ & $1(6.7)$ & $6(40.0)$ & \multirow{4}{*}{14.044} & \multirow{4}{*}{0.121} \\
\hline & Sales & $1(20.0)$ & $2(40.0)$ & $2(40.0)$ & $0(0.0)$ & & \\
\hline & House work & 1 (11.1) & 1 (11.1) & $5(55.6)$ & $2(22.2)$ & & \\
\hline & Sole owner & $2(66.7)$ & $1(33.3)$ & $0(0.0)$ & $0(0.0)$ & & \\
\hline \multirow{4}{*}{$\begin{array}{l}\text { Income (1000 Won/ } \\
\text { Mon) }\end{array}$} & $100-200$ & $1(50.0)$ & $0(0.0)$ & $1(50.0)$ & $0(0.0)$ & \multirow{4}{*}{12.308} & \multirow{4}{*}{0.197} \\
\hline & $200-300$ & $4(36.4)$ & $2(18.2)$ & $3(27.3)$ & $2(18.2)$ & & \\
\hline & $300-400$ & $2(15.4)$ & $2(15.4)$ & 3 (23.1) & $6(46.2)$ & & \\
\hline & Over 400 & $1(16.7)$ & $4(66.7)$ & $1(16.7)$ & $0(0.0)$ & & \\
\hline \multicolumn{2}{|l|}{ Total (N=32) } & $8(25.0)$ & $8(25.0)$ & $8(25.0)$ & $8(25.0)$ & & \\
\hline
\end{tabular}

$\mathrm{G}$, group. 
관리습관), 피부상태(홍반, 수분, TEWL, 거칠기)의 동질성 검증을 위해 chi-squared 검증을 실시하였다.

둘째, 각 그릅의 실험 전과 1 주, 2 주 후에 따른 피부상태 변화를 알아보기 위하여 반복측정 분산분석(repeated measure ANOVA)을 실시하고, 집단 간의 차이를 나타내기 위하여 사후검증 Scheffe를 실시하였다.

\section{Results and Discussion}

\section{1. 그룹간의 일반적 특성 동질성 검증}

일반적 특성 중 평균 나이, 교육 정도, 직업, 월 소득에서 대조군 과 처치군 사이 통계학적으로 유의한 차이를 보이지 않아 집단 간 동질성이 검증되었다(Table 3).

\section{2. 그룹간의 피부상태 동질성 검증}

$\mathrm{G} 1, \mathrm{G} 2, \mathrm{G} 3$ 와 G4의 실험 전 홍반, 수분함유량, TEWL, 거칠기 의 차이는 유의수준 $5 \%$ 에서 유의미하지 않아, 세 군의 동질성이 검 증되었다(Table 4).

\section{1) 홍반변화}

홍반 변화의 사전·사후를 비교한 결과, G1은 필링 전(baseline) $290.13 \pm 42.82$ 에 비해 필링 2주일 후 $288.03 \pm 6.094$ 감소하였 고( $p<0.001), \mathrm{G} 2$ 은 필링 전(baseline) $283.53 \pm 61.95$ 에 비해 필
링 2주일 후 $265.25 \pm 3.196$ 감소하였고( $p<0.001), \mathrm{G} 3$ 은 필링 전 (baseline) 269.25 \pm 39.36 에 비해 필링 2 주일 후 $266.88 \pm 2.532$ 감소하였으며( $p<0.001), \mathrm{G} 4$ 는 필링 전(baseline) $279.65 \pm 79.86$ 에 비해 필링 2 주일 후 $261.75 \pm 21.339$ 감소하여 $(p<0.01)$, 모든 집단 에서 통계학적으로 유의미한 변화가 나타났다.

집단간 차이를 살펴보면 필링 후(15week)의 홍반 변화 차이는 G1, G2, G3, G4 집단 순으로 나타났으며( $p<0.001)$, Farber (1998) 의 연구에서 레티놀 전처치기간이 길수록 필링전 홍반량은 증가하 지만 필링 후엔 전치치 기간이 길수록 홍반량이 감소한 결과와 유사 하였다(Table 5).

처치군인 $\mathrm{G} 2, \mathrm{G} 3, \mathrm{G} 4$ 은 세군 모두 필링 전 홍반 량이 현저 히 증가였다가 필링 2주일(15 week) 후 홍반량이 크게 감소하여 $(p<0.001)$ 통계적으로 유의한 것으로 나타났다(Table 5). 레티노익 산은 콜라겐의 합성의 증가, 미세주름감소, 피부질감의 개선으로 박 피 후 효과를 극대화시키기 위해 전처리로서 유용하지만 레티노이 드산 국소요법의 가장 큰 부작용은 썬번(sun burn)처럼 보이는 홍 반이다(Heinrich et al., 2003). 이는 각질층이 탈락되면서, 새로운 혈관이 형성되고, 팽창되어 혈류량이 급격히 증가되고, 단행세포의 침윤으로 홍반의 특징(Kligman et al., 1986; Lucky et al., 1998) 이 나타나며 피부장벽의 손상 즉, 표피의 구조와 기능에 변화가 일 어나면서 각질형성세포에서 미리 형성되어 있던 $\mathrm{IL}-1 \alpha$ 와 사이토카 인(proinflammatory cytokine)들을 분비하여, 이를 신호로 하여 장 벽복구를 위한 층판소체의 분비가 더욱 활발해지는 동시에 일련의 사이토카인 분비연쇄 반응이 일어나 홍반의 형태로 나타나게 된다

Table 4. Verification the similarity of the skin condition before experiment

\begin{tabular}{lcccccc}
\hline Variables & G1 & G2 & G3 & G4 & $x^{2}$ & $p$ \\
Erythema & $290.13 \pm 42.82^{1)}$ & $36.06 \pm 5.20$ & $12.28 \pm 1.23$ & $18.42 \pm 6.72$ & 0.087 & 0.966 \\
Moisture contents & $283.53 \pm 61.95$ & $34.73 \pm 2.84$ & $11.03 \pm 5.13$ & $22.65 \pm 8.85$ & 0.592 & 0.625 \\
TEWL & $269.25 \pm 39.36$ & $35.21 \pm 5.27$ & $10.03 \pm 1.43$ & $20.57 \pm 2.39$ & 1.337 & 0.282 \\
Roughness & $279.65 \pm 79.86$ & $33.28 \pm 5.37$ & $13.81 \pm 7.03$ & $21.42 \pm 8.71$ & 0.140 & 0.935 \\
\hline
\end{tabular}

TEWL, transepidermal water loss; ${ }^{1)}$ Mean \pm SD.

Table 5. The changes of erythema index on the skin

(Unit: El)

\begin{tabular}{lccccccc}
\hline Variables & Baseline & $\begin{array}{c}13 \mathrm{~W} \\
\text { Peeling day }\end{array}$ & $\begin{array}{c}14 \mathrm{~W} \\
\text { after peeling }\end{array}$ & $\begin{array}{c}15 \mathrm{~W} \\
2 \text { weeks } \\
\text { after peeling }\end{array}$ & $F$ & $p$ & Scheffe \\
G1 & $290.13 \pm 42.82$ & $275.02 \pm 2.726$ & $314.75 \pm 4.892$ & $288.03 \pm 6.094$ & 121.989 & $0.000^{* * *}$ & $\mathrm{~b}, \mathrm{c}>\mathrm{d}$ \\
G2 & $283.53 \pm 61.95$ & $285.04 \pm 5.345$ & $306.13 \pm 4.764$ & $265.25 \pm 3.196$ & 119.730 & $0.000^{* * *}$ & $\mathrm{~b}, \mathrm{c}>\mathrm{d}$ \\
G3 & $269.25 \pm 39.36$ & $293.88 \pm 2.997$ & $298.88 \pm 2.997$ & $266.88 \pm 2.532$ & 54.661 & $0.000^{* * *}$ & $\mathrm{~b}, \mathrm{c}>\mathrm{d}$ \\
G4 & $279.65 \pm 79.86$ & $305.75 \pm 9.114$ & $293.38 \pm 1.685$ & $261.75 \pm 21.339$ & 102.169 & $0.001^{* *}$ & $\mathrm{~b}, \mathrm{c}>\mathrm{d}$ \\
$F$ & 0.087 & $42.736^{* * *}$ & $46.934^{* * *}$ & $8.873^{* * *}$ & & & \\
$p$ & 0.966 & 0.000 & 0.000 & 0.000 & & & \\
Scheffe & - & $\mathrm{a}<\mathrm{b}<\mathrm{c}<\mathrm{d}$ & $\mathrm{a}>\mathrm{b}>\mathrm{c}, \mathrm{d}$ & $\mathrm{a}>\mathrm{b}, \mathrm{c}, \mathrm{d}$ & & &
\end{tabular}

El, erythema index; G, group; W, week; ${ }^{1}{ }^{M}$ ean $\pm S D ;$ Scheffe $(a-d)$, means with letters within a row are statistically different from each other $\left({ }^{* *} p<0.01\right.$; $\left.{ }^{* * *} p<0.001\right)$. 
(Elias, 2008). 13주차(0 week), 처치군의 레티놀 기간이 길수록 홍 반량이 증가하는 종합적인 원인은 신경 감각 입력 신호의 증가, 자 극물질에 대한 비 특이적 면역 반응의 증가, 피부혈관 들의 과민반 응 증가 등의 영향으로 볼 수 있다.

$\mathrm{G} 1$ 은 레티놀 미처리군으로 필링 전 피부장벽이 얇아지지 않고 수 분크림의 지속적인 피부관리의 영향으로 홍반량의 감소가 있었고, 필링 1 주일 후엔 필링으로 인한 자극으로 인해 일시적으로 홍반량 이 증가하였다가, 필링 2주일(15 week) 후 손상된 피부장벽이 회복 되면서 홍반량은 감소하였다. 이는 필링 후 손상된 피부장벽은 피부 속성상 스스로 복구되는 특성을 가지고 있기 때문에 필링 후 2 주 후 엔 원래 상태로 회복된다(Go et al., 2004)라고 한 바, 필링 2주 후 엔 스스로 복원된 피부장벽과 보습크림의 효과로 다시 홍반이 감소 한 것으로 사료된다.

$\mathrm{G} 2, \mathrm{G} 3, \mathrm{G} 4$ 는 필링 전 전처리 기간이 다름에 따른 홍반량의 차 이가 있었으며 전처리 기간과 비례하는 홍반량을 보이며 G4, G3, $\mathrm{G} 2$ 의 순으로 증가폭이 컸다. 필링 전 피부장벽의 손실로 홍반이 크 게 증가하였다가, 필링 후 필링에 대한 자극도 있었지만, 레티놀 사 용이 중지됨과 함께 시간경과에 따른 홍반의 감소가 나타났으며 레 티놀 미 전처리군보다 홍반의 감소가 컸다. West \& Alster (1999)는 레티노익산 전처리군과 미 전처리군에게 레이저 시술 후 과색소침
착 확인결과 미 전처리군에서 더 많이 발생한다고 보고하여 본 연구 와 유사하였다.

\section{2) 수분변화}

수분 변화의 사전·사후를 비교한 결과(Table 6), G1은 필링 전

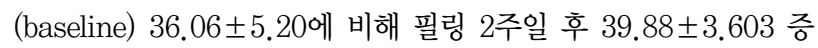

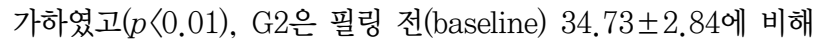
필링 2주일 후 $49.63 \pm 5.829$ 증가하였고( $p<0.01)$, G3은 필링 전

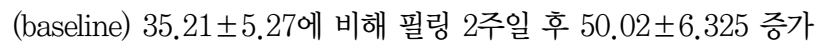
하였으며 $(p<0.01), \mathrm{G} 4$ 는 필링전(baseline) 33.28 5 .37에 비해 필 링 2 주일 후 $51.63 \pm 5.29$ 증가하여 $(p<0.01)$, 모든 집단에서 통계학 적으로 유의미한 변화가 나타났다.

집단간 차이를 살펴보면 필링 후(15week)의 수분 변화 차이는 $\mathrm{G} 1, \mathrm{G} 2, \mathrm{G} 3, \mathrm{G} 4$ 집단 순으로 나타났으며 $(p<0.001)$, 통계적으로 유 의한 것으로 나타났다(Table 6)

Park et al. (2003)의 연구에서 레티놀 도포부위가 대조부위보다 수분 함유량이 많게 나타났다는 결과는 본 연구와 유사하였다. 이는 히알루론산의 생산을 항진시키므로 보습효과가 나타나는 것으로 사 료된다(Margelin et al., 1996). 그러나 Elias (2008), Schmidt et al. (1995), Lucky et al. (1998) 등의 연구에서는 레티노익산 도포

Table 6. The changes of moisture content on the skin

(Unit: \%)

\begin{tabular}{lccccccc}
\hline Variables & Baseline & $\begin{array}{c}13 \mathrm{~W} \\
\text { Peeling day }\end{array}$ & $\begin{array}{c}14 \mathrm{~W} \\
1 \text { weeks } \\
\text { after peeling }\end{array}$ & $\begin{array}{c}15 \mathrm{~W} \\
2 \text { weeks } \\
\text { after peeling }\end{array}$ & $F$ & $p$ & Scheffe \\
G1 & $36.06 \pm 5.20^{1)}$ & $35.01 \pm 1.069$ & $39.88 \pm 4.764$ & $39.88 \pm 3.603$ & 43.761 & $0.000^{* * *}$ & $b<\mathrm{c}, \mathrm{d}$ \\
G2 & $34.73 \pm 2.84$ & $38.63 \pm 1.408$ & $47.13 \pm 5.41$ & $49.63 \pm 5.829$ & 55.129 & $0.000^{* * *}$ & $\mathrm{~b}<\mathrm{c}, \mathrm{d}$ \\
G3 & $35.21 \pm 5.27$ & $41.51 \pm 1.773$ & $48.04 \pm 3.817$ & $50.02 \pm 6.325$ & 73.079 & $0.000^{* * *}$ & $b<\mathrm{c}, \mathrm{d}$ \\
G4 & $33.28 \pm 5.37$ & $45.51 \pm 2.673$ & $51.25 \pm 4.166$ & $51.63 \pm 5.29$ & 44.708 & $0.001^{* * *}$ & $\mathrm{~b}<\mathrm{c}, \mathrm{d}$ \\
F & 0.592 & $47.161^{* * *}$ & $8.783^{* * *}$ & $7.944^{* * *}$ & & & \\
$p$ & 0.625 & 0.000 & 0.000 & 0.001 & & & \\
Scheffe & - & $a<b<c<d$ & $a<b, c, d$ & $a<b, c, d$ & & & \\
\hline
\end{tabular}

G, group; W, week; ${ }^{11}$ Mean $\pm S D ;$ Scheffe (a-d), means with letters within a row are statistically different from each other $\left.{ }^{(* * *} p<0.001\right)$.

Table 7. The changes of TEWL on the skin

(Unit: $g / h / m^{2}$ )

\begin{tabular}{lccccccc}
\hline Variables & Baseline & $\begin{array}{c}13 \mathrm{~W} \\
\text { Peeling day }\end{array}$ & $\begin{array}{c}14 \mathrm{~W} \\
1 \text { weeks } \\
\text { after peeling }\end{array}$ & $\begin{array}{c}15 \mathrm{~W} \\
2 \text { weeks } \\
\text { after peeling }\end{array}$ & $F$ & $p$ & $\begin{array}{c}\text { Scheffe } \\
\text { G1 }\end{array}$ \\
G2 & $12.28 \pm 1.23^{1)}$ & $11.75 \pm 1.282$ & $18.88 \pm 1.808$ & $15.03 \pm 2.0$ & 37.239 & $0.000^{* * *}$ & $\mathrm{~b}<\mathrm{d}<\mathrm{c}$ \\
G3 & $11.03 \pm 5.13$ & $14.5 \pm 0.926$ & $19.13 \pm 2.997$ & $12.63 \pm 1.408$ & 39.831 & $0.000^{* * *}$ & $\mathrm{~d}<\mathrm{b}<\mathrm{c}$ \\
G4 & $10.03 \pm 1.43$ & $16.63 \pm 1.061$ & $20.01 \pm 2.0$ & $10.02 \pm 1.069$ & 59.595 & $0.000^{* * *}$ & $\mathrm{~d}<\mathrm{b}<\mathrm{c}$ \\
F & $13.81 \pm 7.03$ & $21.38 \pm 1.302$ & $22 \pm 2.204$ & $6.88 \pm 0.835$ & 42.302 & $0.001^{* * *}$ & $\mathrm{~d}<\mathrm{b}<\mathrm{c}$ \\
$p$ & 1.337 & 99.378 & 3.048 & 49.906 & & & \\
Scheffe & 0.229 & $0.000^{* * *}$ & $0.045^{*}$ & $0.000^{* * *}$ & & & \\
\hline
\end{tabular}

TEWL, trans epidermal water loss; $\mathrm{W}$, week; ${ }^{1}$ Mean \pm SD; Scheffe (a-d), means with letters within a row are statistically different from each other ( ${ }^{*} p<0.05$; $\left.{ }^{* * *} p<0.001\right)$. 
부위에서 대조군보다 더 건조하다는 보고를 하였는데 이는, 레티놀 이 아닌 자극이 강한 레티노익산을 사용하였기 때문으로 사료된다.

\section{3) TEWL 변화}

TEWL 변화의 사전·사후를 비교한 결과(Table 7), G1은 필링 전 (baseline) $12.28 \pm 1.23$ 에 비해 필링 2 주일 후 $15.03 \pm 2.0$ 증가하 였고( $p<0.001), \mathrm{G} 2$ 은 필링 전(baseline) $11.03 \pm 5.13$ 에 비해 필 링 2 주일 후 $12.63 \pm 1.408$ 증가하였고 $(p<0.001)$, G3은 필링 전 (baseline) $10.03 \pm 1.43$ 에 비해 필링 2 주일 후 $10.02 \pm 1.069$ 감소 하였으며( $p<0.001), \mathrm{G} 4$ 는 필링 전(baseline) $13.81 \pm 7.03$ 에 비해 필링 2 주일 후 $6.88 \pm 0.835$ 감소하여 $(p<0.001)$, 모든 집단에서 통 계학적으로 유의미한 변화가 나타났다.

집단간 차이를 살펴보면 필링 후(15week)의 TEWL 변화 차이는 $\mathrm{G} 1, \mathrm{G} 2, \mathrm{G} 3, \mathrm{G} 4$ 집단 순으로 나타났으며 $(p<0.001)$, 통계적으로 유 의한 것으로 나타났다(Table 7).

$\mathrm{G} 1$ 은 TEWL 변화량이 필링 1주일 후 급격히 증가하였다가 필링 2 주 후 다시 감소하였는데, 이는 필링 1 회 후 약초필링으로 피부장 벽이 손상되었다가 필링 2 주 후 자연치유력과 보습크림의 피부장벽 대체 효과로 인해 다시 감소하게 된다.

$\mathrm{G} 2$ 는 처치군에도 불구하고 TEWL이 증가된 것은 레티놀 전처치 기간이 짧아 각질층 탈락이 미미 했음으로 사료된다.

처치군인 $\mathrm{G} 3, \mathrm{G} 4$ 는 필링 전 증가하였다가 필링 2 주후 다시 감소 하였다. 레티놀 사용으로 인한 피부장벽의 손상은 피부 항상성 회복 반응이 칼슘 변화를 유발한다. 정상적으로 표피는 칼슘 기울기가 있 어 칼슘이온 농도는 기저층과 유극층에서 낮고 상층으로 갈수록 증 가하여 상부 과립층에서 가장 높다. 피부장벽의 손상은 피부의 상 부로부터 수분손실을 유도하고, 이로 인한 수분손실은 표피 내 칼 슘감소로 인한 칼슘 기울기의 변화를 초래한다(Sung et al., 2000). 즉, 표피 내의 피부손상으로 떨어진 칼슘이온의 감소 및 칼슘 이온 기울기의 변화로 층판소체의 분비 및 지질 합성과 $\mathrm{IL}-1 \alpha, \mathrm{IL}-6$, $\mathrm{TNF}-\alpha, \mathrm{TGF}-\beta$ 같은 사이토카인의 분비가 촉진됨으로써 피부 장 벽 회복(Go et al., 2004)되어 TEWL이 감소하게 된다.
또한 Kim et al. (1997) 연구에서 화학 박피술을 시행할 때 최초 의 흰 서리(white frost)가 나타날 때까지 면봉으로 TCA 용액을 도 포한 횟수는, 레티노익산을 전처리 하지 않은 군에서는 평균 20.5회 였고 레티노익산을 전처리한 군에서는 3.6회로 두 비교군간에 통계 학적으로 유의미한 차이 $(p<0.01)$ 가 있었다고 한바, 전처리 군에서 표피가 얇아져 TEWL 변화량이 증가한 결과와 유사하였다.

사실, 필링 후 손상된 피부장벽은 피부 속성상 스스로 복원되는 특성을 가지고 있기 때문에 필링 후 2 주 후엔 원래 상태로 회복된다 (Kim et al., 2011). 그러나, 필링 전 레티놀 전처리로 경피수분손실 을 미리 유발하여 사이토카인의 분비증가, 칼슘농도 변화와 칼슘이 온 기울기의 변화로 인한 지질의 합성증대로 상피화 과정을 촉진시 켜 상처치유 기간을 줄이고 피부의 과 색소침착을 줄여 피부를 개선 시킬 수 있다(Effendy et al., 1995; Hung et al., 1989; Mandy, 1986; Popp et al., 1995; Vagotis \& Brundage, 1995).

따라서 필링의 부작용인 과색소침착, 저색소침착, 비후성 반흔이 나 켈로이드, 감염, 지속적인 홍반이나 소양증, 피부의 위축, 한진 등의 부작용을 최소화하고 피부개선을 극대화하자는 것이 필링전 레티놀 전처리의 의의라 사료된다.

\section{4) 거칠기 변화}

거칠기 변화의 사전·사후를 비교한 결과, G1은 필링 전(baseline) $18.42 \pm 6.72$ 에 비해 필링 2 주일 후 $18.88 \pm 0.991$ 증가하였고 ( $p<0.001), \mathrm{G} 2$ 은 필링 전(baseline) $22.65 \pm 8.85$ 에 비해 필링 2주 일 후 $16.63 \pm 0.916$ 감소하였고 $(p<0.001), \mathrm{G} 3$ 은 필링 전(baseline) $20.57 \pm 2.39$ 에 비해 필링 2 주일 후 $13.88 \pm 0.991$ 감소하였으며 ( $p<0.001), \mathrm{G} 4$ 는 필링 전(baseline) $21.42 \pm 8.71$ 에 비해 필링 2 주 일 후 $11.02 \pm 1.69$ 감소하여 $(p<0.001)$, 모든 집단에서 통계학적으 로 유의미한 변화가 나타났다.

집단간 차이를 살펴보면 필링 후(15week)의 거칠기 변화 차이는 $\mathrm{G} 1, \mathrm{G} 2, \mathrm{G} 3, \mathrm{G} 4$ 집단 순으로 나타났으며 $(p<0.001)$, 통계적으로 유 의한 것으로 나타났다(Table 8).

이와 같은 결과는 박피술 후 조직학적 변화는 응고되었던 조직

Table 8. The changes of roughness on the skin

(Unit: Pixel)

\begin{tabular}{|c|c|c|c|c|c|c|c|}
\hline Variables & Baseline & $\begin{array}{c}13 \mathrm{~W} \\
\text { Peeling day }\end{array}$ & $\begin{array}{c}14 \mathrm{~W} \\
1 \text { weeks } \\
\text { after peeling }\end{array}$ & $\begin{array}{c}15 \mathrm{~W} \\
2 \text { weeks } \\
\text { after peeling }\end{array}$ & $F$ & $p$ & Scheffe \\
\hline G1 & $18.42 \pm 6.72^{1)}$ & $19.75 \pm 1.832$ & $15.03 \pm 2.928$ & $18.88 \pm 0.991$ & 36.925 & $0.000^{* * *}$ & $c<b, d$ \\
\hline G2 & $22.65 \pm 8.85$ & $12.88 \pm 0.835$ & $15.13 \pm 2.997$ & $16.63 \pm 0.916$ & 43.381 & $0.000^{* * *}$ & $b<c, d$ \\
\hline G3 & $20.57 \pm 2.39$ & $16.5 \pm 2.07$ & $15.13 \pm 2.416$ & $13.88 \pm 0.991$ & 56.978 & $0.000^{* * *}$ & $d<b, c$ \\
\hline G4 & $21.42 \pm 8.71$ & $20.75 \pm 2.816$ & $14.51 \pm 2.673$ & $11.02 \pm 1.69$ & 63.488 & $0.001^{* * *}$ & $d<c<b$ \\
\hline$F$ & 0.140 & $44.185^{* * *}$ & 0.093 & $65.738^{* * *}$ & & & \\
\hline$p$ & 0.935 & 0.000 & 0.963 & 0.000 & & & \\
\hline Scheffe & - & $a<b<c<d$ & - & $a>b>c>d$ & & & \\
\hline
\end{tabular}

G, group; W, week; ${ }^{1}$ Mean $\pm S D$; Scheffe (a-d): means with letters within a row are statistically different from each other $\left({ }^{* * *} p<0.001\right)$. 
이 치유되면서 표피는 박피시술 전보다 더 조직적으로 정렬되었으 며, 진피는 표피층과 평행하게 잘 정렬되고 조밀한 두꺼운 층의 콜 라겐이 새롭게 생성되어 노화된 피부의 소생에 효과적이었음을 알 수 있어 레티노익산으로 전처리한 군에서 박피술 후 시간 별 조직 학적 변화로 살펴볼 때 표피의 재생과 진피에서 콜라겐 섬유의 생 성 속도 및 성숙도가 전처리 하지 않은 군에 비해 더 빨랐다(Kim et al., 1997)는 본 연구와 유사하였다. 또한 레티노익산 전처리 군의 전자 현미경 소견에서 모낭에서 유사 분열 수치는 횔씬 더 증가하였 고, 세포소기관의 세포질을 가지고 있으며 상부 진피의 섬유아세포 가 더 컸다며 레티노익산 전처리는 TCA의 효과를 지속하고 상처 치 유 강화하여 TCA 시너지 효과를 보여 주었다(Kim et al., 1997)라 는 결과를 보고 한 바, 필링 전 레티놀 전처리군의 콜라겐 생성으로 인한 상피화가 촉진되어 대조군에 비해 빠른 거칠기 감소가 이루어 진 것으로 사료된다. 필링은 피부의 죽은 각질층을 얇게 벗겨 내 피 부의 결을 말끔하게 정돈해 주는 시술이며, 이는 손상된 표피와 진 피 일부를 제거하여 새로운 피부가 재생되는 효과를 이용한 것이다 (Park et al., 2003; Song, 2007)라고 선행 논문에서 언급한 바, 네 군 모두 필링을 시행함으로써 각질제거를 통한 거칠기 감소가 이루 어졌을 뿐 아니라 처치군에서 더 빨리 거칠기 감소가 이루어졌음은 레티놀이 각질형성세포의 증식과 분화를 조절한다는 이론을 뒷받침 하고 있다(Kim et al., 2009).

\section{Conclusion}

본 연구에서는 약초필링 이전에 기간이 다른 레티놀 전 처리가 필 링 후 발생하는 부작용을 최소화하고 피부 개선 효과를 검증하고자 하였다.

이에 필링 전 기간이 다른 레티놀 전 처리가 피부 개선에 미치 는 영향에 대해 실험한 결과 G1은 수분 증가 TEWL 증가(12.28$>15.03)$, 거칠기 증가(18.42->18.88), 홍반(290.13->288.03)에 서 감소한 것으로 나타나 실험 전과 비교하여 통계학적으로 유의 미한 변화가 있었다. G2는 수분 증가(34.73->49.63), TEWL 다 소 증가(11.03->12.63), 홍반(283.53->265.25), 거칠기(22.65$>16.63)$ 에서 감소한 것으로 나타나 실험 전과 비교하여 통계학적 으로 유의미한 변화가 있었다. G3도 수분 증가(35.21->50.02), 홍 반(269.25->266.88), TEWL (10.03->10.02), 거칠기(20.57$>13.88$ )에서 감소한 것으로 나타나 실험 전과 비교하여 통계학적 으로 유의미한 변화가 있었다. G4 또한 수분 증가(33.28->51.63), 홍반(279.65->261.75), TEWL (13.81->6.88), 거칠기(21.42$>11.02)$ 에서 크게 감소한 것으로 나타나 실험 전과 비교하여 통계학 적으로 유의미한 변화가 있었고, G4가 홍반, 수분 증가, TEWL, 거 칠기에서 전체적으로 큰 변화 량이 나타났으며, 특히 홍반과, TEWL 에서 매우 높은 변화를 보였다. 이는 Olsen et al. (1997), Mandy
(1986), West \& Alster (1999)의 연구 결과와 같이 레티노익산의 도 포 횟수가 많을수록 피부개선에 더 효과적임을 알 수 있었다. 또한 Jeon et al. (1998)의 보고와 같이 레티노익산 보다 자극이 적은 레 티놀의 사용이 안전하며 사용기간이 길 경우 피부개선에 효과적임 을 알 수 있었다. 전체 G1, G2, G 3, G4 집단간 홍반, 수분, TEWL, 거칠기의 변화량 비교에서 G4 집단이 가장 높은 변화를 가져왔으 며, 다음으로 G3 집단, G2 집단, G1 집단의 순으로 변화폭이 감소 하였고, 네 군 사이에 유의한 차이가 나타났다.

이상의 결과를 바탕으로 필링 전 기간을 달리한 레티놀 전처리는 기간이 증가할수록 홍반, 수분 부족, 피부자극증상을 개선, 완화하 는데 있어 긍정적인 효과를 나타내므로, 향후 피부 개선에 가장 효 과적인 전처리로써의 레티놀 함량에 따른 제제의 안정성, 사용기간 에 관한 연구가 좀 더 다양하고 폭넓게 진행되어 필링 전 전처리 프 로그램으로써 대중화가 될 수 있도록 적극 활용되기를 기대한다.

This work is part of the Seongeun Oh's M.S. thesis at the Dongduk Women's University, Seoul, Korea.

\section{Author's contribution}

SEO and CGJ contributed equally to this work. SEO and CGJ designed all experimental investigations, and participated in all experiments. SEO collected SPSS data, experimental design and oversaw the project, and contributed to all aspects of analysis and experimental design. SEO wrote the manuscript with assistance from CGJ.

\section{Author details}

Seongeun Oh (Graduate student), Department of Applied Chemistry, Dongduk Women's University, 60 Hwarangro, 13-gil, Seongbuk-gu, Seoul 02748, Korea; ChangGok Chang (Professor), Dongduk Women's University, 60 Hwarang-ro, 13-gil, Seongbuk-gu, Seoul 02748, Korea.

\section{References}

Deprez P. Textbook of chemical peels: superficial, medium, and deep peels in cosmetic practice. Informa healthcare, Abingdon, p14, 2007.

Duke D, Grevelink JM. Care before and after laser skin resurfacing. a survey and review of the literature. Dermatologic Surgery, 24: 201-206, 1998.

Effendy I, Kwangsukstith C, Lee JY, Maibach HI. Functional 
changes in human stratum corneum induced by topical glycolic acid: comparison with all-trans retinoic acid. Acta Dermato-Venereologica, 75: 455-458, 1995.

Elias PM. Barrier repair trumps immunology in the pathogenesis and therapy of atopic dermatitis. Drug Discovery Today: Disease Mechanisms, 5: 33-38, 2008.

Farber GA. Prolonged erythema after chemical peel. Dermatologic Surgery, 24: 934-935, 1998.

Go JY, Jeong SG, Lee SH, Lee CU. The effects of topical glycolic acid on the expression of epidermal cytokines and epidermal calcium gradient of hairless mice. Korean Journal of Dermatology, 42: 290-299, 2004.

Heinrich U, Gärtner C, Wiebusch M, Eichler O, Sies H, Tronnier $\mathrm{H}$, Stahl W. Supplementation with $\beta$-carotene or a similar amount of mixed carotenoids protects humans from UVinduced erythema. The Journal of Nutrition, 133: 98101, 2003.

Ho ET, Trookman NS, Sperber BR, Rizer RL, Spindler R, Sonti S, Gotz V, Mehta R. A randomized, double-blind, controlled comparative trial of the anti-aging properties of nonprescription tri-retinol $1.1 \%$ vs. prescription tretinoin 0.025\%. Journal of Drugs in Dermatology, 2012, 11: 6469, 2012.

Hung VC, Lee JY, Zitelli JA, Hebda PA. Topical tretinoin and epithelial wound healing. Archives of Dermatology, 125: 65-69, 1989.

Jeon HD Lee SY, Lee HJ, Park YL, Lee JS, Whang KU. The effects of retinol to eye wrinkles. Journal of Soonchunhyang Medical Science, 4: 333-342, 1998

Kim DM, Kim MS, Jeon YS, Lee SY. The effects of amino fruit acid peeling and diamond peeling on the skin of women in their thirties. Asian Journal of Beauty and Cosmetology, 9: 1-9, 2011.

Kim EJ, Lee SH. The effect of seaweeds scaling and glycolic acid peeling on the acne skin. Asian Journal of Beauty and Cosmetology, 8: 11-19, 2010.

Kim EY, Jeon HJ, Hae JC, Kang SO. The effects of $30 \%$ glycolic acid liquid form and cream form on middle-age women of 30s and 40s. Asian Journal of Beauty and Cosmetology, 10: 929-940, 2012.

Kim HB, Kim JY, An S, Lee YJ, Cho DH, Kim HS, Bae S. Potential anti-wrinkle activity of Chlorella sp. HS1-derived oil components on human dermal fibroblasts. Asian Journal of Beauty and Cosmetology, 18: 41-51, 2020.
Kim HS, Choi YH. Comparative study on changes in skin condition according to peeling care techniques. Asian Journal of Beauty and Cosmetology, 16: 82-92, 2018.

Kim KB, Kim JY An SW, Min ES, Bae SH. Evaluation of the perception and clinical characteristics of facial skin aging according to age-group among Korean women. Asian Journal of Beauty and Cosmetology, 18: 387-396, 2019.

Kim HJ, Koo SH, Park SH, Ahn DS. Experimental study of histological changes of TCA chemical peel and effects of retinoic acid. Archives of Plastic Surgery, 24: 1261-1273, 1997.

Kim YK, Jang KJ, Lee SH, An SK, Choe TB. The effect of microneedle therapy system and alpha hydroxy acid peeling on the pores and the hyperpigmentation of men's skin. Asian Journal of Beauty and Cosmetology, 7: 69-79, 2009.

Kligman AM, Grove GL, Hirose R, Leyden JJ. Topical tretinoin for photoaged skin. Journal of the American Academy of Dermatology, 15: 836-859, 1986.

Lee NK, Ku JE, Han HS. Cytoprotective and anti-inflammatory effects of 6-shogaol on human dermal fibroblasts. Asian Journal of Beauty and Cosmetology, 15: 367-376, 2017.

Lucky AW, Cullen SI, Funicella T, Jarratt MT, Jones T, Reddick ME. Double-blind, vehicle-controlled, multicenter comparison of two $0.025 \%$ tretinoin creams in patients with acne vulgaris. Journal of the American Academy of Dermatology, 38: 24-30, 1998.

Mandy SH. Tretinoin in the preoperative and postoperative management of dermabrasion. Journal of the American Academy of Dermatology, 15: 878-879, 1986.

Margelin D, Medaisko C, Lombard D, Picard J, Fourtanier A. Hyaluronic acid and dermatan sulfate are selectively stimulated by retinoic acid in irradiated and nonirradiated hairless mouse skin. The Journal of Investigative Dermatology, 106: 505-509, 1996.

Olsen EA, Katz HI, Levine N, Nigra TP, Pochi PE, Savin RC, Shupack J, Weinstein GD, Lufrano L, Jou HC. Sustained improvement in photodamaged skin with reduced tretinoin emollient cream treatment regimen: effect of once-weekly and three-times-weekly applications. Journal of the American Academy of Dermatology, 37: 227-230, 1997.

Olson JA. Recommended dietary intakes (RDI) of vitamin A in humans. The American Journal of Clinical Nutrition, 45: 
704-716, 1987.

Park JS, Kim KH, Chung KY. Comparative study of glycolic acid peeling vs. tretinoin peeling in facial pigmentary lesions. Korean Journal Dermatology, 41: 841-846, 2003.

Park SH, Lee JN. The effect of glycolic acid peeling and seaweed peeling on keratosis pilaris. Journal of the Korea Academia-Industrial Cooperation Society, 13: 492504, 2018.

Popp C, Kligman AM, Stoudemayer TJ. Pretreatment of photoaged forearm skin with topical tretinoin accelerates healing of full-thickness wounds. British Journal of Dermatology, 132: 46-53, 1995.

Schmidt JB, Binder M, Macheiner W, Bieglmayer C. New treatment of atrophic acne scars by iontophoresis with estriol and tretinoin. International Journal of Dermatology, 34: 53-57, 1995.

Shin HW. The effects of retinol on the keratosis piliaris (Master dissertation). Konkuk University, Seoul, pp16-17, 2009.

Sohn BK, Wie HG, Chung YJ. A effect of pretreatment period on $\mathrm{CO}_{2}$ laser Resurfacing in guinea pig skin: a comparative, histologic study. Archives of Plastic Surgery, 30: 623-627, 2003.

Song $\mathrm{JH}$. After in peeling care applying AsA, the eesults of skin stimulus and change of sebum, moisture, keratin. Journal of the Korean Society of Esthetic \& Cosmeceutics, 2: 125-136, 2007.

Sung KJ, Choi EH, Hwang SM, Suh DH, Lee SH. The efficacy and safety of isotretinoin in Korean patients with mild to moderate acne. Korean Journal Dermatology, 38: 13091314, 2000.

Underwood BA. Vitamin A in animal and human nutrition. In The retinoids (Vol. I). Sporn MB, Roberts A, Goodman DS (eds.), Academic Press, New York, pp281-392, 1984.

Vagotis FL, Brundage SR. Histologic study of dermabrasion and chemical peel in an animal model after pretreatment with retin-A. Aestheric Plasctic Surgery, 19: 243-246, 1995.

West TB, Alster TS. Effect of pretreatment on the incidence of hyperpigmentation following cutaneous $\mathrm{CO}_{2}$ laser resurfacing. Dermatologic Surgery, 25: 15-7, 1999. 


\section{국문초록}

\section{레티놀의 전처치 기간에 따른 Herbal Peeling의 피부 개선 효과}

오성은, 장창곡*

동덕여자대학교 보건향장학과, 서울, 한국

목적: 본 연구의 목적은 약초필링 이전에 기간이 다른 레티놀 전처리가 필링 후 발생하는 부작용을 최소화하고 피부 개선 효과를 검 증하고자 하였다. 방법: 약초필링 전 레티놀로 전처리 하지 않은 그룹을 Group 1 (G1, 대조군), 약초필링전 4주간(8주-12주) 레티 놀로 전처리한 그룹을 Group 2 (G2), 약초필링전 8주간(4주-12주) 레티놀로 전처리한 그룹을 Group 3 (G3), 약초필링 전 12주간(1 주-12주) 레티놀로 전처리한 그룹을 Group 4 (G4)로 하였다. 연구기간은 총 15 주간 진행되었는데, 필링전 레티놀 전처리 기간 시 작점을 달리하여 G 4는 첫 주부터, G 3 은 4주째부터, G 2 은 8주째부터 레티놀 적용 홈케어를 하였다. 실험 전, 13 주차(필링 1 주일) 및 15 주차(필링 2 주 후)의 피부 홍반 지수, 수분 함량, TEWL 및 거칠기를 측정하였다. 결과: 본 연구를 통해 기간이 다른 레티놀 전처리가 수분증가와 홍반, TEWL 및 거칠기의 감소를 확인할 수 있었다. 레티놀 전처리 그룹은 미전처리 그룹보다 홍반이 낮으며, 유의한 차이가 있는 것으로 나타났다. 또한 레티놀 전처리 그룹은 미전처리 그룹보다 보습이 높았으며, 유의한 차이가 있는 것으로 나타났다. 레티놀 전처리 그룹은 미전처리 그룹보다 TEWL 및 거칠기가 낮았을 뿐만 아니라 유의한 차이가 있는 것으로 밝혀졌다. 홍반, 수분, TEWL, 거칠기에서 G4는 G3보다 더 큰 변화가 있었고 G3은 G2보다 더 컸다. 따라서 장기적인 레티놀 전처리 그룹은 홍반, 탈수, 피부 자극 개선 및 완화에 긍정적인 효과가 있는 것으로 확인됐다. 결론: 이상의 결과를 바탕으로 필링 전 기간을 달리 한 레티놀 전처리는 기간이 증가할수록 홍반, 수분 부족, 피부자극증상을 개선, 완화하는데 있어 긍정적인 효과를 나타내므로, 향후 피부 개선에 가장 효과적인 전처리로써의 레티놀 함량에 따른 제제의 안정성, 사용기간에 관한 연구가 좀 더 다양하고 폭넓게 진행 되어 필링 전 전처리 프로그램으로써 대중화가 될 수 있도록 적극 활용되기를 기대한다.

핵심어: 레티놀, 전처리, 다양한 시간, 약초필링, 피부개선

\section{참고문헌}

고주연, 정세규, 이승헌, 이창우. Glycolic acid 국소도포가 무모생쥐의 표피내 사이토카인 및 칼슘이온 기울기에 미치는 영향에 관한 연구. 대한피부과학회지, 42: 290-299, 2004.

김기쁨, 김지예, 안성관, 민은설, 배승희. 한국 성인 여성의 연령별 얼굴 노화 정도에 대한 인식과 임상학적 특성에 관한 연 구. 아시안뷰티화장품학술지, 18: 387-396, 2019.

김동미, 김미성, 전연숙, 이시경. 아미노 필링과 다이아몬드 필링이 30 대여성 피부에 미치는 영향. 아시안뷰티화장품학술 지, 9: 1-9, 2011.

김연경, 장경자, 리순화, 안성관, 최태부. 미세 다륜침(MTS)과 AHA필링이 남성피부의 모공과 색소침착에 미치는 영향. 아시안뷰티화장품학술지, 7: 69-79, 2009.

김은영, 전해정, 강신옥. $30 \%$ Glycolic acid 리퀴드제형과 크림제형이 30-40대 중년여성 피부상태에 미치는 효과. 아시안 뷰티화장품학술지, 10: 929-940, 2012.

김은주, 리순화. 해초 스케일링과 글리콜릭산 필링이 여드름 피부에 미치는 영향. 아시안뷰티화장품학술지, 8: 11-19, 2010.

김형준, 구상환, 박승하, 안덕선. TCA 화학 박피술의 피부 조직학적 변화와 Retinoic Acid의 효과에 대한 실험적 연구. Archives of Plastic Surgery, 24: 1261-1273, 1997.

김혜빈, 김지예, 안성관, 이용재, 조대현, 김희식, 배승희. 인간 진피섬유아세포에서 Chlorella sp. HS1 유래 오일의 콜라 겐 발현 증가 효력에 관한 연구. 아시안뷰티화장품학술지, 18: 41-51, 2020. 
박서연, 이재남. 글릭콜릭산 필링과 해초 필링이 모공각화증 피부에 미치는 영향. 한국산학기술학회논문지, 13: 492504, 2018.

박준수, 김경호, 정기양. 안면의 색소성 질환에서 Glycolic acid 박피술과 Tretinoin 박피술의치료 효과에 대한 비교연구. 대한피부과학회지, 41: 841-846, 2003.

성경제, 최응호, 황상민, 서대헌, 이승헌. 한국인에서 경도 및 중등도의 여드름에 대한 경구 Isotretinoin의 유효성 및 안정 성 평가. 대한피부과학학회지, 38: 1309-1314, 2000.

신혜원. 레티놀이 모공각화증에 미치는 영향. 석사학위논문, 건국대학교, 서울, pp16-17, 2009.

손병규, 위형곤, 정윤재. 전 처치 기간에 따른 이산화탄소레이저 박피술을 시행한 기니아피그 피부의 조직학적 변화에 대 한 실험 연구. Archives of Plastic Surgery, 5: 623-627, 2003.

송지혜. 아스코프빅산 필링 후 피부자극 및 유 - 수분, 각질 변화 연구. 한국피부미용향장학회지, 2: 125-136, 2007.

이나경, 구정은, 한효선. 인간진피섬유아세포에서 6-Shogaol의 세포보호 및 항염증 효과. 아시안뷰티화장품학술지, 15: 367-376, 2017.

전희대, 이성열, 이혜진, 박영림, 이종석, 황규왕. Retinol 국소도포에 의한 눈가주름 제거효과. 순천향의대논문집, 4 : 333-342, 1998. 


\section{中文摘要}

\section{根据视黄醇预处理阶段对中药脱皮后皮肤的改善作用}

吳誠恩, 張昌谷

同德女子大学保健香妆学科，首尔，韩国

目的: 视黄醇是一种维生素A衍生物，可通过在草药剥皮之前在患处皮肤上多次使用视黄醇来进行预处理，以最 大程度地减少副作用并治䏒受损的皮肤。然而, 视黄醇作为预处理的作用尚不清楚。因此, 这项研究评估了视 黄醇作为改善皮肤状况的预处理的效果。方法: 招募中年妇女作为研究对象, 分为四组, 即不进行视黄醇预处理 (G1) ，视黄醇预处理4周（G2），8周（G3）和12周（G4）。该测试进行了15次。在剥皮之前，在 $G 1 ， G 3$ 和 G4组中的参与者在指定的时间段内使用视黄醇乳霜对皮肤进行了预处理，而在G1中的参与者未接受预处理。在 实验前, 剥皮当天以及剥皮后1和 2 周测量皮肤红斑指数, 水分含量, 表皮失水量 (TEWL) 和粗糙度。结果: 预 处理组和非预处理组之间的皮肤红斑指数, 水分含量, TEWL和粗糙度均存在显着差异。与未处理组相比, 预处 理组的水分含量更高, 红斑更少, TEWL更低, 粗糙度更低。另外, G4比G3具有更大的改进, 并且G3比G2具有 更大的改进。结论: 结果表明，长期使用视黄醇可有效缓解红斑，脱水和皮肤刺激。

关键词：视黄醇，预处理，各种时间，草药去皮，改善皮肤 